Article

\title{
Benchmark Comparison of High Voltage Discharge Separation of Photovoltaic Modules by Electrohydraulic and Electrodynamic Fragmentation
}

\author{
Fadri Pestalozzi ${ }^{1, *(1)}$, Stefan Eisert ${ }^{2}$ and Jörg Woidasky ${ }^{1}$ (i) \\ 1 Pforzheim University of Applied Sciences, School of Engineering, 75175 Pforzheim, Baden-Württemberg, \\ Germany; joerg.woidasky@hs-pforzheim.de \\ 2 ImpulsTec GmbH, 01129 Dresden, Sachsen, Germany; stefan.eisert@impulstec.com \\ * Correspondence: fadri.pestalozzi@hs-pforzheim.de; Tel.: +49-7231-28-6877
}

Received: 4 December 2017; Accepted: 9 April 2018; Published: 10 April 2018

\begin{abstract}
Recent years have seen an increasing interest in exploring alternative techniques to conventional grinding methods such as fragmentation by high voltage discharges. Although pulsed power has already been applied to break down complex composite materials, there is currently no systematic comparison between different types of discharge regimes such as electrohydraulic and electrodynamic fragmentation. The aim of this work is to present such a comparison based on the electrohydraulic and electrodynamic fragmentation of copper indium diselenide (CIS) photovoltaic modules for potential indium recovery. High voltage discharges are performed in a process vessel filled with demineralized water at ambient conditions. After fragmentation, individual fractions are weighed, milled and the indium content is determined by X-ray fluorescence (XRF). Both the electrohydraulic and the electrodynamic approach are suitable to efficiently separate thin-film photovoltaic composite material into its constituent layers. The separation result is not dependent on the voltage level, but only on the total pulse energy applied. Since the generation of discharges with higher voltages requires a higher investment into plant properties such as insulation and generator, a comminution at lower voltages, i.e., electrohydraulic fragmentation, is preferable to electrodynamic fragmentation at higher voltages. To reveal the specific strengths of the two processes compared here, further comparative work with different composite materials is required.
\end{abstract}

Keywords: pulsed power; high voltage discharge; fragmentation; electrohydraulic; electrodynamic; comparison; benchmark; thin-film photovoltaic; CIS; indium recovery

\section{Introduction}

The separation requirements for recycling processes are steadily increasing due to the growing material diversity of modern products [1], rising demands on recovery rates [2] as well as on the quality of recycled materials [1,3]. Current separation techniques for material composites such as photovoltaic modules involve mechanical comminution and the subsequent use of aggressive chemicals and/or heat treatment [1]. Recent years have seen an increasing interest in exploring alternative comminution techniques such as fragmentation by high voltage discharges [4,5]. The main advantage of electrodynamic fragmentation compared to mechanical comminution is its improved selectivity during the separation process, which can improve downstream process efficiency [6]. Although high voltage discharges have already been applied to break down complex composite materials, there is currently no systematic comparison between different types of pulsed power applications. The aim of this work is to present such a comparison based on the fragmentation of photovoltaic (PV) modules of type CIS (copper indium diselenide [7-9]) as a model material. 
Between 2000 and 2010, the capacity of PV modules installed globally rose from 1.4 to 40.7 GW, and the total mass of PV modules produced in 2010 amounts to 2.5 million tons [10]. With an estimated lifespan of 20 years, this same amount of obsolete PV modules will accrue by the year 2030 [11]. Since the production of PV is both cost and energy intensive [12], there is a need for efficient recycling processes. A prerequisite for materials recycling is the proper separation of material composites. Current methods for the separation of PV modules use chemical, thermal and mechanical steps [13]. As an alternative, the use of high voltage discharges for the fragmentation of thin film CIS-PV panels in a process vessel filled with demineralized water is presented here. In a benchmark study, two different regimes of electrical discharge generation are compared, namely the electrodynamic and the electrohydraulic approach (see Table 1).

Table 1. Pulsed power generators used for benchmark analysis.

\begin{tabular}{ccccc}
\hline $\begin{array}{c}\text { Fragmentation } \\
\text { Method, Acronym }\end{array}$ & Plant, Acronym & $\begin{array}{c}\text { Voltage } \\
\text { Range [kV] }\end{array}$ & $\begin{array}{c}\text { Pulse Rise } \\
\text { Time }[\boldsymbol{\mu s}]\end{array}$ & $\begin{array}{c}\text { Process } \\
\text { Volume [L] }\end{array}$ \\
\hline $\begin{array}{c}\text { Electrodynamic, } \\
\text { EDF }\end{array}$ & $\begin{array}{c}\text { SelFrag Lab S2.1, SF } \\
\text { ImpulsTec EHF-100 }\end{array}$ & $90-200$ & $0.15-0.2$ & 2.6 \\
$\begin{array}{c}\text { Electrohydraulic, } \\
\text { EHF }\end{array}$ & $\begin{array}{c}30-50 \\
\text { Research System, IT }\end{array}$ & $0.5-2$ & 0.9 \\
\hline
\end{tabular}

Publications on the recycling potential of electrodynamic fragmentation focus on the comminution of concrete [14-23], separation of incinerator bottom ash $[4,6,14,15,20]$, disassembly of waste electrical equipment $[6,14,15,24-26]$ and separation of carbon fibre reinforced plastic [20,27-29]. Publications on the recycling potential of electrohydraulic fragmentation include the removal of chromium electroplating layers [30], disassembly of waste electrical equipment [30] and separation of carbon fibre reinforced plastic [31]. Market introduction of pulsed power facilities is being performed by SelFrag AG (SF; electrodynamic, Kerzers/Switzerland, established 2007 [32]) and ImpulsTec GmbH (IT; electrohydraulic, Dresden, Germany, established 2014 [33]).

\section{Materials and Methods}

A thin-film PV module (type CIS, Würth Solar GmbH \& Co. KG, Schwäbisch Hall, Germany, WS11007-75, thickness $6.4 \mathrm{~mm}$ ) was cut into pieces of $22 \times 22 \mathrm{~mm}$ using a conventional tile cutter (diamond cutting disc). The layer structure of CIS-PV comprises a film of EVA (ethylene-vinyl acetate, thickness $0.7 \mathrm{~mm}$ ), which connects two glass support layers, each of $2.9 \mathrm{~mm}$ thickness. The CIS semiconductor layer (thickness approx. $2 \mu \mathrm{m}$ ) is enclosed between the EVA film and the glass support on the front side facing the light.

This sample material is fragmented by high voltage pulses from two different pulsed power generators (see Table 1). The electrodynamic fragmentation (EDF) was performed with a plant by SelFrag AG (Kerzers, Switzerland), located at Pforzheim University. The electrohydraulic fragmentation (EHF) was carried out at an in-house plant by ImpulsTec GmbH (Dresden, Germany). Table 1 shows the specifications of both plants used. Depending on the geometry, relative position and composition of the sample material, both plants perform a superposition of both EDF and EHF. SF generates primarily EDF and IT primarily EHF. The difference between EDF and EHF is illustrated in Figure 1 identifying EDF to occur with shorter pulses below approximately $500 \mathrm{~ns}$, where the dielectric strength $\left(\mathrm{E}_{\mathrm{d}}\right)$ of the solid sample material is found to be below the one of water. Applying a high enough voltage $\left(U_{\max }\right)$ within a sufficiently low pulse rise time of $t_{U \max }<500$ ns hence allows the subsequent discharge to penetrate through a solid material sample within the process water. Figure 2 shows sample current waveforms measured by a commercially available oscilloscope during discharges of the ImpulsTec installation. The curves at 30 and $40 \mathrm{kV}$ exhibit the same time period. The current amplitude increases due to an increased discharge voltage from 30 to $40 \mathrm{kV}$. For discharges at $50 \mathrm{kV}$ a different generator with a lower capacity was used. Therefore, the corresponding period is 
lower compared to waveforms at 30 and $40 \mathrm{kV}$. If it had been possible to do the $50 \mathrm{kV}$ pulse experiments with the same experimental setup as for 30 and $40 \mathrm{kV}$, the period would have remained the same and the amplitude would have increased further. The SelFrag installation does not allow access to its control unit in order to record waveforms.

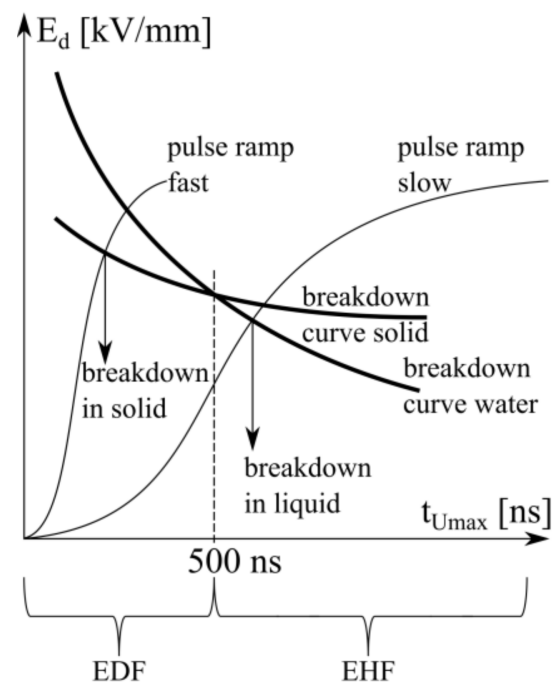

Figure 1. Electrodynamic and electrohydraulic breakdown regimes according to [15]. Correlation between dielectric strength $\mathrm{E}_{\mathrm{d}}$ and pulse rise time $\mathrm{t}_{\mathrm{Umax}}$.

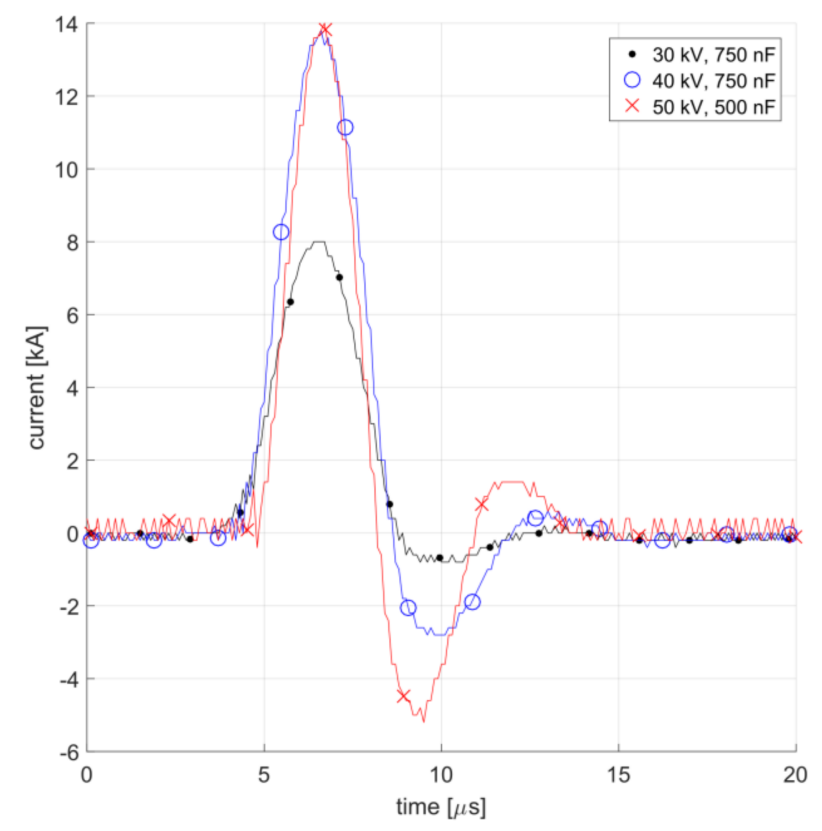

Figure 2. Discharge current of ImpulsTec installation from oscilloscope measurements.

In order to compare the two pulsed power generators used, individual experiments are performed with identical total pulse energy. Equation (1) displays the pulse energy $E_{P}$ of a plate capacitor with capacitance $C$ and voltage $U$ according to [34]:

$$
E_{P}=1 / 2 \times C \times U^{2}
$$

Summing up all pulses $(\mathrm{P})$ yields the total pulse energy $\left(\mathrm{E}_{\mathrm{P}, \mathrm{tot}}\right)$ : 


$$
\mathrm{E}_{\mathrm{P}, \text { tot }}=\mathrm{E}_{\mathrm{P}} \times \mathrm{P}
$$

To achieve constant $E_{P, t o t}$ for different $C$ and $U$, the number of pulses $P_{x}$ is adjusted as follows:

$$
\mathrm{P}_{2}=\mathrm{P}_{1} \times\left(\mathrm{C}_{1} / \mathrm{C}_{2}\right) \times\left(\mathrm{U}_{1} / \mathrm{U}_{2}\right)^{2}
$$

To determine the value of $E_{P, t o t}, P$ is iteratively increased at $\mathrm{U}=30 \mathrm{kV}$ until a pre-defined liberation value of $\mathrm{L}>80 \%$ is reached. Liberation $\mathrm{L}$ is defined as the glass share which is removed from the PV sample material and hence does no longer adhere to the EVA layer. To determine L, both the mass of residual glass adhering to EVA ( $\mathrm{m}_{\text {glass on } \mathrm{EVA}}$ ), as well as the total glass mass within the sample $\left(\mathrm{m}_{\text {glass total }}\right)$ have to be determined:

$$
\mathrm{L}=1-\left(\mathrm{m}_{\text {glass on } \mathrm{EVA}} / \mathrm{m}_{\text {glass total }}\right)
$$

This results in a total pulse energy of $\mathrm{E}_{\mathrm{P}, \text { tot }}=12 \mathrm{~kJ}$ for each individual experiment (Figure 3). Each test series consists of five individual runs, with a sample mass of $100 \mathrm{~g}$ per run. In addition, two runs at $40 \mathrm{kV}$ were performed using a capacitor with a smaller capacitance, reducing the energy of individual discharges from $600 \mathrm{~J}\left(\mathrm{E}_{\mathrm{hi}}\right)$ to $100 \mathrm{~J}\left(\mathrm{E}_{\mathrm{lo}}\right.$, see Figure 3$)$. The length of the error bars is twice the standard deviation with the center position at the mean value of the particular data set. While keeping both the initial mass $\left(\mathrm{m}_{0}\right)$ as well as the total pulse energy $\left(\mathrm{E}_{\mathrm{P}, \text { tot }}\right)$ constant, the comminution energy amounts to approx. $120 \mathrm{~J} / \mathrm{g}$ (Figure 3). In tests with the SF plant, the desired voltage was not reached. The desired and achieved voltage ranges are 140-200 kV (desired) versus 117-134 kV (achieved experimentally). According to SelFrag AG, the gas circuit fan was defective and hence was replaced in the meantime. This fan circulates nitrogen gas between capacitor plates within the pulse generator, thus removing burn-off particles between capacitor plates. A build-up of particles in the spark gaps between individual capacitor plates leads to a decrease in breakdown voltage. In order to keep $E_{P, t o t}$ as constant as possible, the number of pulses was adapted to the average voltage reached during each specific experiment on a case-to-case basis (Figure 3).

After comminution, the process vessel was emptied over two sieves of screen sizes 1 and $0.125 \mathrm{~mm}$. The solid fragments were dried (Thermo Fisher Scientific, Karlsruhe, Germany , drying cabinet VT 6025, $30 \mathrm{~min}$ at $120^{\circ} \mathrm{C}$ ) and sieved (Retsch $\mathrm{GmbH}$, Haan, Germany, AS 200 digit, sieving time $5 \mathrm{~min}$, screen sizes in $\mathrm{mm}[0.125 / 0.18 / 0.25 / 0.5 / 1 / 2.5 / 4 / 6.3])$. The process water was filtered (IDL, round filter type black, pore size $20 \mu \mathrm{m}$ ) and the filter paper was incinerated during $15 \mathrm{~min}$ at $600{ }^{\circ} \mathrm{C}$ (Carbolite Gero $\mathrm{GmbH} \& \mathrm{Co} . \mathrm{KG}$, Neuhausen, Germany, ashing furnace AAS 11/7). Four fractions were recovered: 1. process water, 2. solids from filter, 3. solids from sieve and 4. EVA film with residual solid adhesions. Subsequently, the individual solid fractions both from sieving and ashing were weighed (balance by Kern \& Sohn GmbH, Balingen, Germany, ABT 220-5DM) and ground after immersion in liquid nitrogen (ultracentrifugal mill by Retsch GmbH, Haan, Germany, ZM200 with sieve insert of $250 \mu \mathrm{m}$ mesh size). Finally, the indium concentration was determined by means of a mobile XRF device (X-ray fluorescence, Analyticon Instruments $\mathrm{GmbH}$, Rosbach vor der Höhe, Germany, Niton XL2air, environmental test program with $\mathrm{Cu} / \mathrm{Zn}$ ). The XRF measurement program was calibrated in advance with a 3-point calibration by means of wet chemical analysis to determine the indium content (ICP-OES at Technische Universität Darmstadt, Darmstadt, Germany).

To measure the power consumption of an entire plant $\left(\mathrm{E}_{\mathrm{A}, \text { tot }}\right)$, a current meter (PCE Deutschland $\mathrm{GmbH}$, Meschede, Germany, Easycount-3-32-A) is interposed between the power supply and the plant. The standby consumption of each plant is measured overnight and subtracted from the total reading to quantify the power consumption due to the generation of discharges. The pulse efficiency $\eta_{A P}$ describes the conversion efficiency of plant energy to pulse energy:

$$
\eta_{\mathrm{AP}}=\mathrm{E}_{\mathrm{P}, \text { tot }} / \mathrm{E}_{\mathrm{A}, \text { tot }}
$$




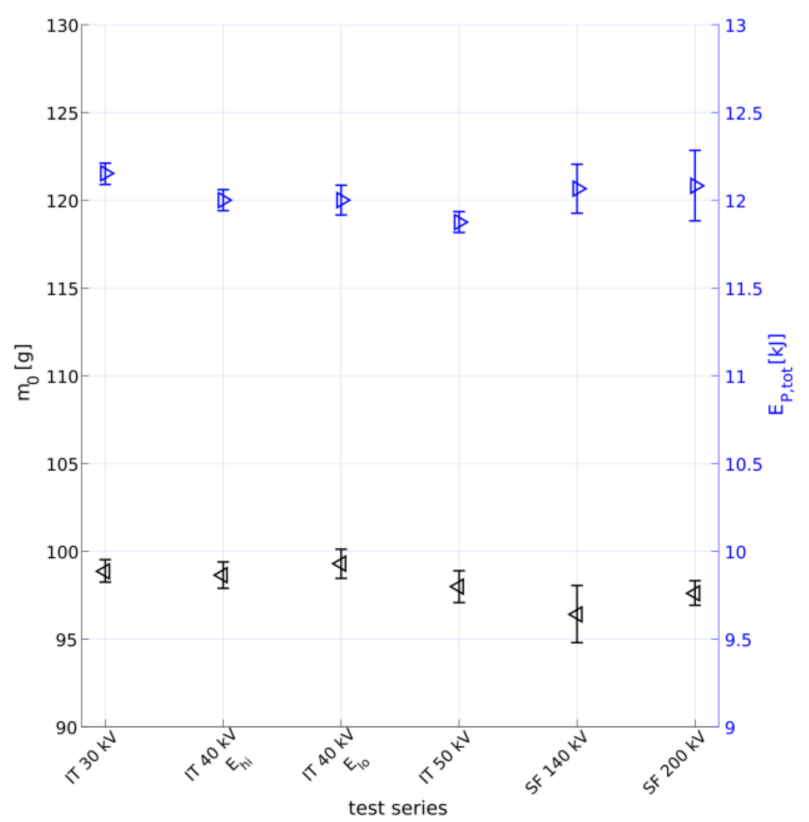

Figure 3. Sample mass $\left(\mathrm{m}_{0}\right.$, left-pointing triangles) and total pulse energy ( $\mathrm{E}_{\mathrm{P}, \text { tot }}$, right-pointing triangles) were kept constant for all test series. The abscissa holds increasing voltage levels, generated with the two plants by ImpulsTec (IT) and SelFrag (SF).

\section{Results}

\subsection{Median Particle Size}

The energy of individual discharges varies depending on the voltage and capacitance used (Equation (1)), ranging from $\mathrm{E}_{\mathrm{P}}=100 \mathrm{~J} / \mathrm{P}$ to $625 \mathrm{~J} / \mathrm{P}$. The resulting fragmentation decreases the sample size from an initial $22 \times 22 \times 6.4 \mathrm{~mm}$ down to a median particle size $\left(\mathrm{D}_{50}\right)$ of 0.75 to $1.29 \mathrm{~mm}$ (Figure 4$)$.

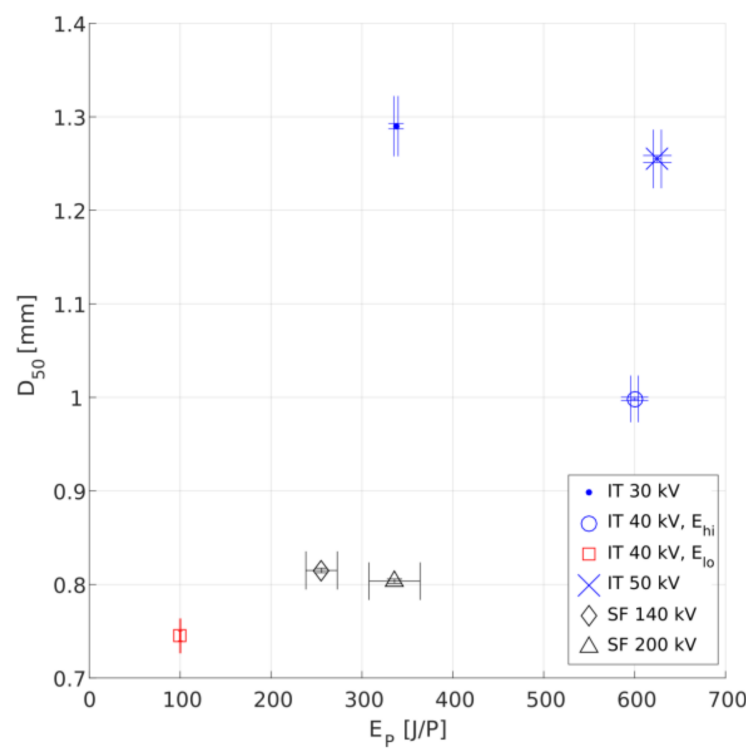

Figure 4. Energy of individual pulses $\left(E_{P}\right)$ and median particle size $\left(D_{50}\right)$ of individual test series. 


\subsection{Distribution of Mass and Indium Content}

Figure $5 \mathrm{~b}$ shows the sum of indium to be found in the particle size fractions. This figure was determined by multiplication of the mass (Figure 5a) with the indium concentration (Figure 6) of individual particle size fractions.

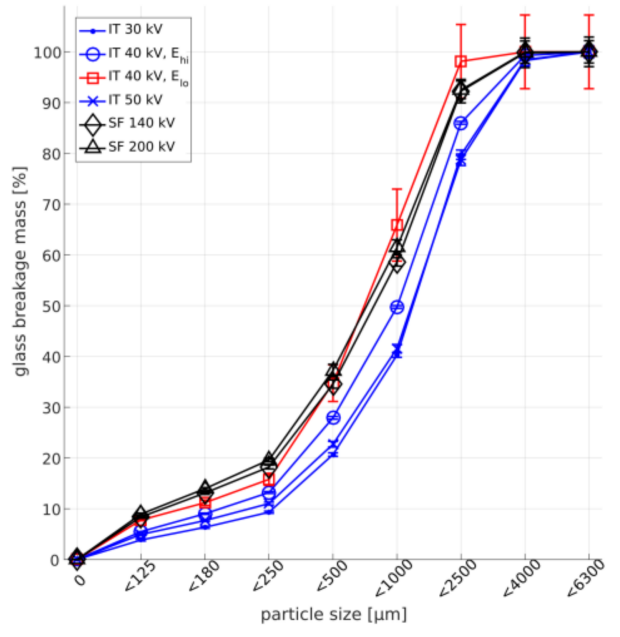

(a)

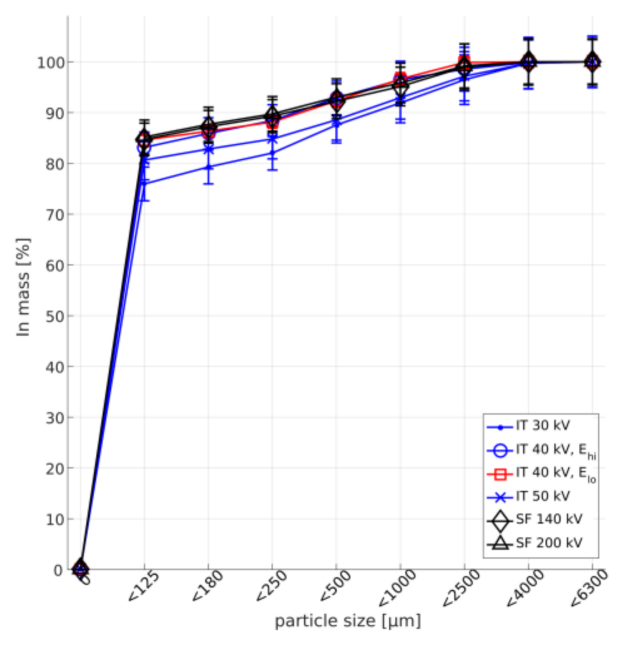

(b)

Figure 5. Cumulative particle size distribution of: (a) Glass breakage from filtration and sieve analysis; (b) Mass of indium detected within glass breakage from filtration and sieve analysis.

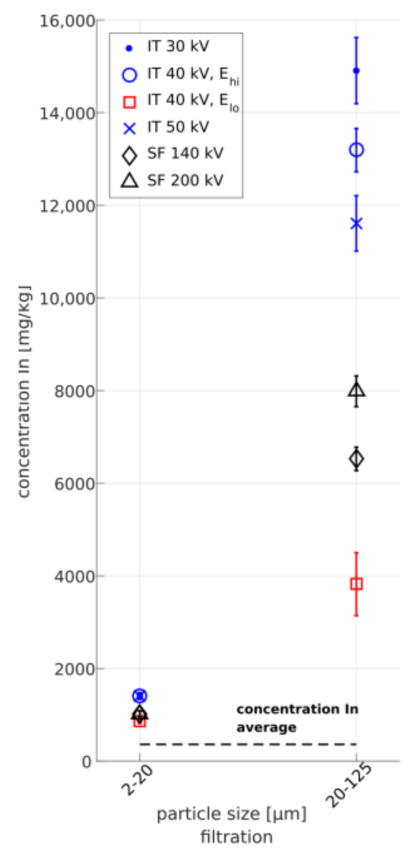

(a)

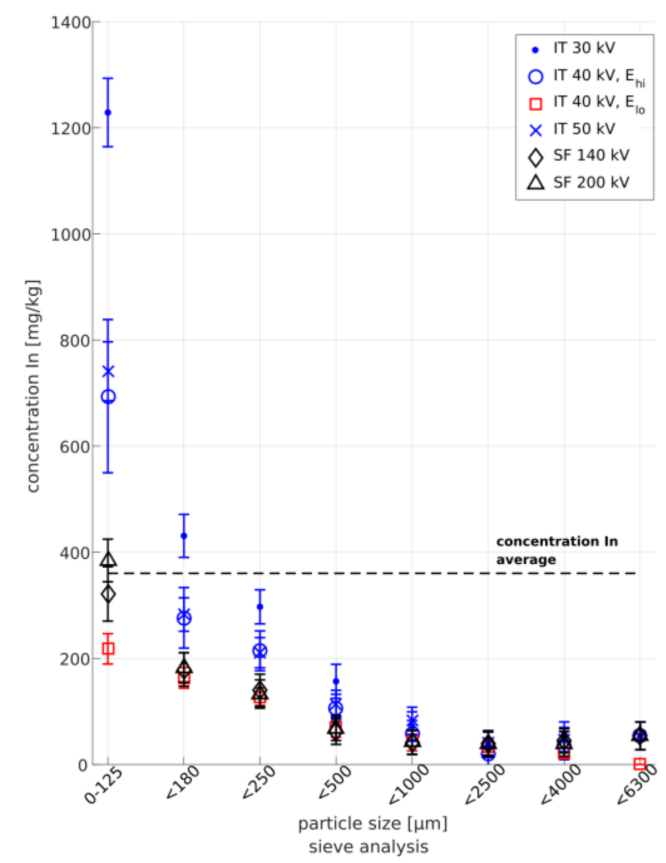

(b)

Figure 6. Indium concentration of individual particle size fractions from (a) Filtration and; (b) Sieve analysis. Average concentration determined by milling of original material.

The distribution of the indium contents across the four fractions of process water (aq.), filter content, sieve content and residual adhesion on top of the EVA film is shown in Figure 7. The fraction dissolved in the process water is not visible in Figure 7 due to the low values of $0.1-0.2 \%$. 


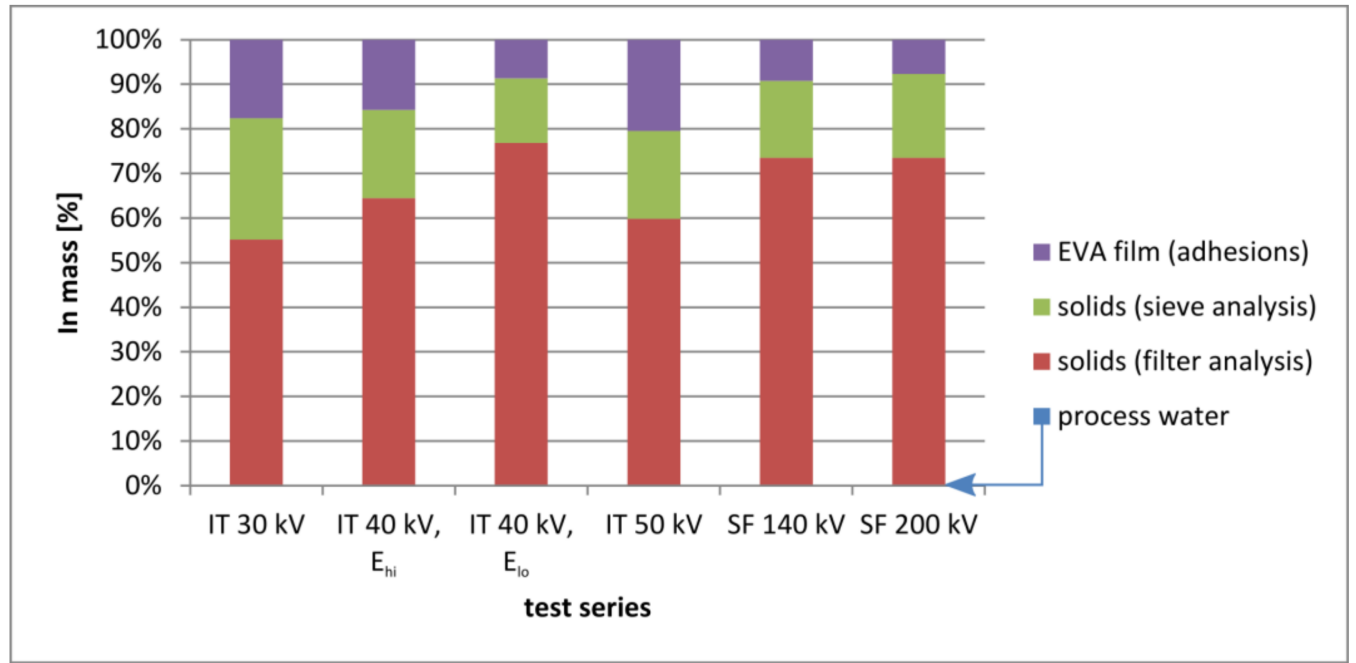

Figure 7. Distribution of indium mass of individual test series. Low values for process water of $0.1-0.2 \%$ not visible.

\subsection{Liberation}

In Figure 8a, the liberation L (Equation (4)) of different test series is compared with the residual

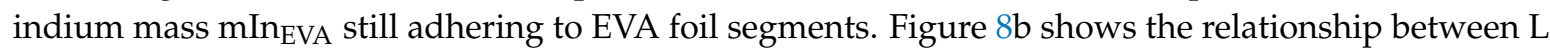
and $\mathrm{D}_{50}$. Figure 9 shows the relationship between $\mathrm{L}$ and $\mathrm{E}_{\mathrm{P}}$.

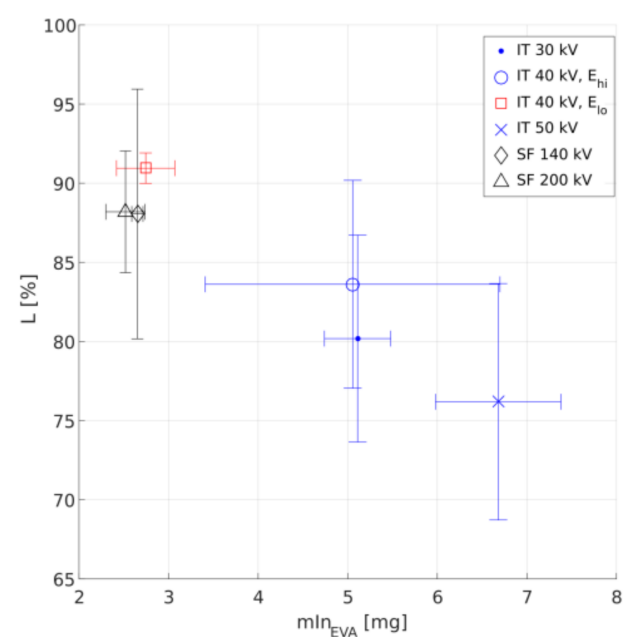

(a)

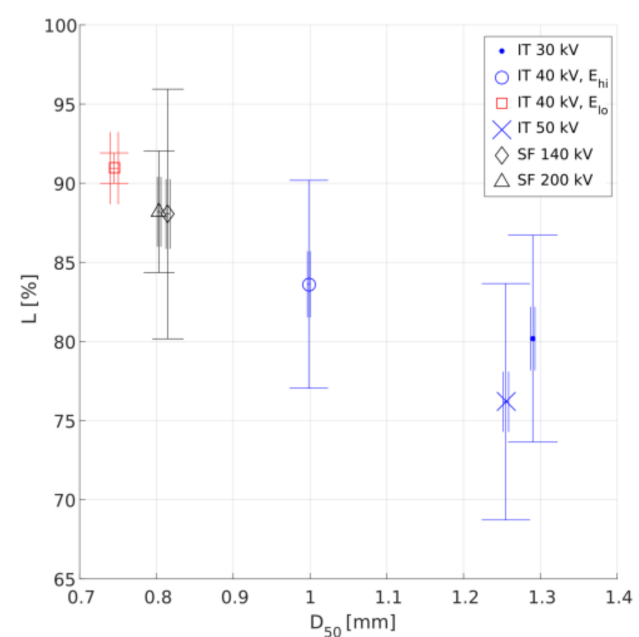

(b)

Figure 8. Comparison of liberation (L) with: (a) Residual indium content of EVA film pieces (mIn $\mathrm{EVA}_{\mathrm{EA}}$ ) and; (b) Median particle size $\left(\mathrm{D}_{50}\right)$. 


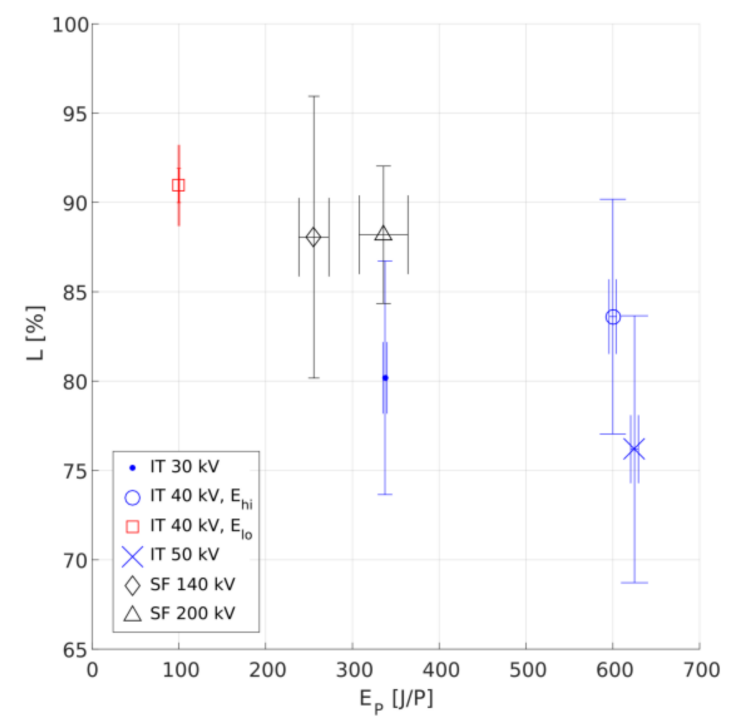

Figure 9. Comparison of liberation (L) and energy of individual discharges $\left(\mathrm{E}_{\mathrm{P}}\right)$.

\subsection{Recovery and Efficiency}

The recovery rate of indium after fragmentation is shown in Figure 10a. The pulse efficiency $\left(\eta_{A P}\right)$ at specific voltage levels is shown in Figure 10b. $\eta_{\mathrm{AP}}$ is used to compare the two installations used.

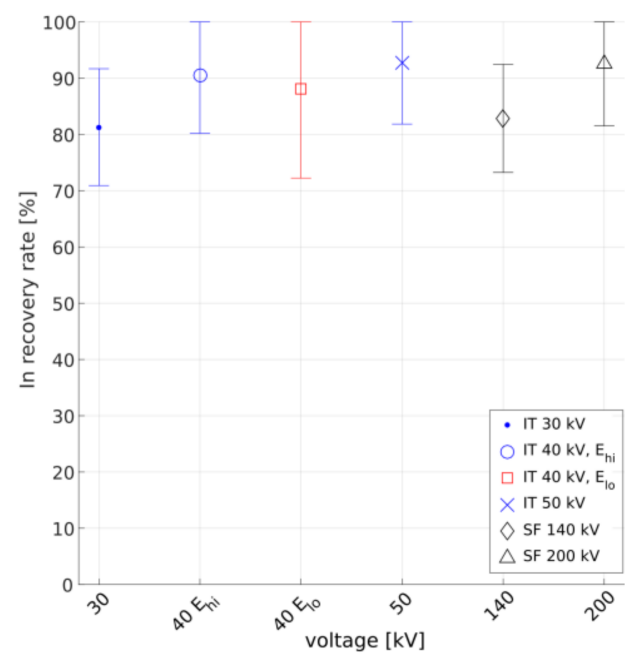

(a)

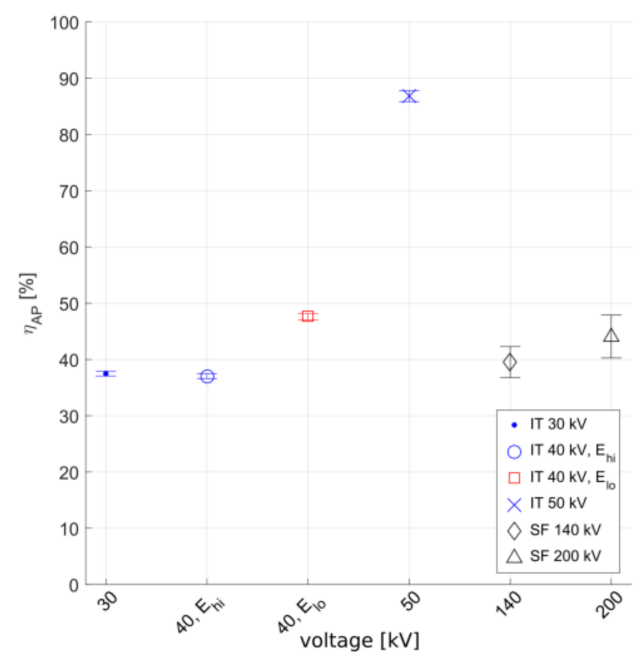

(b)

Figure 10. Values of individual test series with respect to: (a) Indium recovery rate and; (b) Pulse efficiency $\left(\eta_{\mathrm{AP}}\right)$.

\section{Discussion}

As can be seen in Figure 4, lower values for $\mathrm{D}_{50}$ were achieved by fragmentation at low single discharge energy $E_{P}$ and thus higher number of discharges P. Hence, the comminution success of high voltage discharges onto PV panels is not primarily dependent on the intensity of individual discharges but rather on the amount of discharges and the total pulse energy introduced. This is probably due to the brittle nature of the glass being the main component of solar modules. The tendency of discharges with lower $E_{P}$ to reach higher L (Figure 9) is advantageous for separating thin film PV. The generation of as many low- $E_{P}$ discharges as possible can be achieved either by a lower capacitance or a lower voltage (Equation (1)). In Figure 4 the test series at $30 \mathrm{kV}$ stands out from this trend with the maximum 
value of $\mathrm{D}_{50}=1.29 \mathrm{~mm}$ at $\mathrm{E}_{\mathrm{P}}=340 \mathrm{~J} / \mathrm{P}$. This could be indicative of a lower comminution effect at discharges under a certain threshold voltage.

As expected, after fragmentation of PV the main share of indium is located in the fine particle fraction $(<125 \mu \mathrm{m}$, Figure $5 \mathrm{~b})$. After filtration and sieve analysis, the fine grain glass fraction contains $4-9 \%$ of the mass and $76-85 \%$ of the indium content of the ground PV. According to expectation, the three test series with the smallest values for $D_{50}$ and $E_{\mathrm{P}}\left(40 \mathrm{kV} \mathrm{E} \mathrm{E}_{\mathrm{o}} / 140 \mathrm{kV} / 200 \mathrm{kV}\right)$ contain the largest indium mass in the fine grain (Figure $5 b$ ). This is another indication for a link between better comminution and lower energy of single discharges, corresponding to a higher number of discharges applied. As shown in Figure 6, the In concentration of fine grain decreases from $(30 \mathrm{kV} / 40$ $\left.\mathrm{kV} \mathrm{E} E_{\mathrm{hi}} / 50 \mathrm{kV}\right)$ over the test series with the SF plant to the tests with lower $\mathrm{E}_{\mathrm{P}}\left(40 \mathrm{kV} \mathrm{E} \mathrm{E}_{\mathrm{lo}}\right)$ which simultaneously also reaches the lowest $\mathrm{D}_{50}$ value (Figure $8 \mathrm{~b}$ ). A possible correlation between the indium concentration in the fine grain and the median particle size $\mathrm{D}_{50}$ could be an indication of progressive comminution of mostly pure glass (i.e., basically In free) particles, which are thus mixed with the semiconductor particles in the fine grain. Depending on the further use of comminution products, one could focus either on obtaining a filtrate with maximum concentration of precious semiconductor metals, or on the highest possible separation of metals such as indium from the material composite. The overall distribution of the indium contents (Figure 7) gives a similar picture as in Figure 6. The series of tests with the better comminution result (lower $\mathrm{D}_{50}$ values) are capable of transferring a larger proportion of the indium originally attached to the EVA film into the filter fraction. Comminuting CIS-PV by means of high voltage discharges thus at the same time can concentrate the contained semiconductor metal indium in the fine grain as well as clean the coarse grain of such semiconductor material. With the exception of the $\mathrm{D}_{50}$ value at $30 \mathrm{kV}$, no influence of the selected voltage on the comminution result was determined. The exposure appears rather to depend on the energy of individual discharges (Figure 4). As shown in Figure 8a, the indium mass adhering to the EVA film after fragmentation decreases with increasing liberation L. Within the observed ranges of liberation values, the liberation gives a good approximation to determine the amount of semiconductor layer which was separated from a PV composite by means of high voltage discharges. Since the determination of $L$ only requires the initial mass and the dry mass of EVA film pieces, the separation success can thus be determined much more easily and quickly. As shown in Figure 8b, the median grain size decreases with increasing liberation, which is to be expected with the progress of comminution.

The test series at 30 and $140 \mathrm{kV}$ lead to an indium recovery rate of $81 \%$ and $83 \%$ respectively, which is lower than the remaining series of experiments, where $88 \%$ to $93 \%$ of initial indium were recovered (Figure 10a). This may indicate initially higher handling losses, particularly in the case of the indium-rich fine fraction. The tests at 30 and $140 \mathrm{kV}$ were the first test series performed at the IT and SF plants respectively. With $37-48 \%$ pulse efficiency, the IT plant at 30 and $40 \mathrm{kV}$ is in the same range as the SF plant with values from $40 \%$ to $44 \%$ (Figure 10b). The outlier at IT $50 \mathrm{kV}$ with $87 \%$ is due to a different charging mechanism. Therefore, the measured values are in proximity of the theoretical efficiency maximum of a marx generator of $50 \%$.

All data, code and resulting figures are accessible online as Supplementary Materials (see link below).

\section{Conclusions}

As a result of an experimental benchmark study, both the electrohydraulic as well as the electrodynamic method are suitable to efficiently separate thin-film PV composite material into its constituent layers. In this case, the separation result is not dependent on the voltage level, but only on the total pulse energy applied. Since the generation of discharges with higher voltages requires a higher investment into plant properties such as insulation and generator [15], a comminution at lower voltages, i.e., electrohydraulic fragmentation (IT), is preferable to electrodynamic fragmentation (SF) at higher voltages. To reveal the specific strengths of the two processes compared here, further comparative work with different composite materials is required. 
Supplementary Materials: The following are available online at http://www.mdpi.com/2313-4321/3/2/13/s1, data_and_code.zip.

Acknowledgments: This study is funded equally by a scholarship of Fadri Pestalozzi by the German Federal Environmental Foundation (Deutsche Bundesstiftung Umwelt, Osnabrück, Germany) as well as by the research department of ImpulsTec GmbH (Dresden, Germany). No additional funding was acquired for publication. Thanks go to Christiane Brockmann (IWAR institute at TU Darmstadt) for the wet chemical analysis using ICP-OES on the process water as well as to calibrate the XRF device. We would also like to thank Dieter Geyer from the Center for Solar Energy and Hydrogen Research Baden-Württemberg (ZSW) for providing CIS-PV sample material. Finally, thanks go to Thomas Hirth for his supervision of the Fadri Pestalozzi.

Author Contributions: The experiments were conceived, designed and performed by Fadri Pestalozzi. The experiments at $40 \mathrm{kV}$ with lower pulse energy were performed by Sergej Vitovtov (employee at ImpulsTec). Fadri Pestalozzi compiled and analyzed the data and generated the figures. Fadri Pestalozzi wrote the initial paper draft. Jörg Woidasky and Stefan Eisert performed substantial proof-reading to attain the current quality of the paper.

Conflicts of Interest: The authors declare no conflict of interest. The fact that the experimental campaign as well as data analysis was performed by Fadri Pestalozzi and that the paper was thoroughly reviewed and proofread by Jörg Woidasky relieves Stefan Eisert from a possible bias towards the ImpulsTec technology. The founding sponsors had no role in the design of the study; in the collection, analyses, or interpretation of data; in the writing of the manuscript, and in the decision to publish the results.

\section{References}

1. Martens, H.; Goldmann, D. Recyclingtechnik. Fachbuch für Lehre und Praxis, 2nd ed.; Springer Vieweg: Berlin, Germany, 2016; ISBN 978-3-658-02786-5.

2. European Commission (EC) Directive 2008/98/EC of the European Parliament and of the Council of 19 November 2008 on Waste and Repealing Certain Directives (Waste Framework Directive); European Commission: Strasbourg, France, 2008.

3. Schug, H.; Eickenbusch, H.; Marscheider-Weidemann, F.; Zweck, A. Zukunftsmarkt Technologien zur Stofferkennung und -Trennung. Fallstudie im Auftrag des Umweltbundesamtes, UBA-Fkz. 206 14 132/05. Available online: https:/ / www.umweltbundesamt.de/en/node/7453 (accessed on 28 March 2018).

4. Weh, A.; Käppeler, J. Industrieller Einsatz des Hochspannungsimpuls-Verfahren zur Aufbereitung von Verbrennungsrückständen. In 13. Recy E DepoTech-Konferenz; Montanuniversität Leoben: Leoben, Austria, 2016; pp. 135-140.

5. Lieberwirth, H. Elektroimpulszerkleinerung in Großtechnischen Zerkleinerungsmaschinen zur Aufbereitung Komplexer Erze (ELIZE), BMBF FKZ: 033R161. Available online: http:/ / tu-freiberg.de/ elize (accessed on 28 March 2018).

6. Weh, A. Effiziente Metallrückgewinnung aus Kehrichtverbrennungsasche mittels Hochspannungsimpulsverfahren. In Mineralische Nebenprodukte und Abfälle; Thome-Kozmiensky, K., Ed.; TK Verlag Karl Thome-Kozmiensky: Neuruppin, Germany, 2015; Volume 2, pp. 167-191. ISBN 978-3-944310-21-3.

7. Gustafsson, A.M.K. Recycling of CIGS Solar Cell Waste Materials; Chalmers University of Technology: Gothenburg, Sweden, 2014.

8. Berger, W.; Simon, F.-G.; Weimann, K.; Alsema, E.A. A novel approach for the recycling of thin film photovoltaic modules. Resour. Conserv. Recycl. 2010, 54, 711-718. [CrossRef]

9. Goetzberger, A.; Hebling, C.; Schock, H.-W. Photovoltaic materials, history, status and outlook. Mater. Sci. Eng. R Rep. 2003, 40,1-46. [CrossRef]

10. EPIA (European Photovoltaic Industry Association) Global Market Outlook for Photovoltaics 2013-2017. Available online: http:/ / www.fotovoltaica.com/fv-look.pdf (accessed on 29 November 2017).

11. Fischer, K.; Koch, M.; Metzger, J. Photovoltaikmodule-Umweltfreundlichkeit und Recyclingmöglichkeiten. Abschlussbericht für das Ministerium für Umwelt, Klima und Energiewirtschaft Baden Württemberg. Available online: http://www.iswa.uni-stuttgart.de/ch/img/Download_pdf/PV_Abschlussbericht_1_ 18072012.pdf (accessed on 29 November 2017).

12. Goe, M.; Gaustad, G. Strengthening the case for recycling photovoltaics: An energy payback analysis. Appl. Energy 2014, 120, 41-48. [CrossRef] 
13. Sander, K.; Zangl, S.; Reichmuth, M.; Schröder, G. Stoffbezogene Anforderungen an Photovoltaik-Produkte und deren Entsorgung. Umwelt-Forschungs-Plan. FKZ 20233304 Endbericht. Available online: https: / / www.umweltbundesamt.de/sites/default/files/medien/publikation/long/2789.pdf (accessed on 29 November 2017).

14. Bluhm, H.; Frey, W.; Giese, H.; Hoppe, P.; Schultheiss, C.; Strässner, R. Application of Pulsed HV Discharges to Material Fragmentation and Recycling. IEEE Trans. Dielectr. Electr. Insul. 2000, 7, 625-636. [CrossRef]

15. Bluhm, H. Pulsed Power Systems, Principles and Applications, 1st ed.; Springer: Berlin/Heidelberg, Germany, 2006; ISBN 978-3-540-34662-3.

16. Schultheiss, C.; Straessner, R.; Bluhm, H.; Stemmennann, P. Concrete recycling and scraping by electrodynamic fragmentation. In Physics of Intense Light Ion Beams, Production of High Energy Density in Matter, and Pulsed Power Applications; Annual Report 1996/97, FZKA-6205; Bluhm, H., Ed.; Karlsruhe Institute of Technology: Karlsruhe, Germany, 1999; p. 218.

17. Akiyama, H.; Sakai, S.; Sakugawa, T.; Namihira, T. Environmental Applications of Repetitive Pulsed Power. IEEE Trans. Dielectr. Electr. Insul. 2007, 14, 825-833. [CrossRef]

18. Weh, A.; Monti di Sopra, F. Zerkleinerung und Aufschluss von Abfallströmen mittels gepulster Hochspannungstechnologie. In Recycling und Rohstoffe; Thome-Kozmiensky, K., Ed.; TK Verlag Karl Thome-Kozmiensky: Neuruppin, Germany, 2011; Volume 1, pp. 371-378. ISBN 978-3-935317-67-2.

19. Menard, Y.; Bru, K.; Touze, S.; Lemoign, A.; Poirier, J.E.; Ruffie, G.; Bonnaudin, F.; Von Der Weid, F. Innovative process routes for a high-quality concrete recycling. Waste Manag. 2013, 33, 1561-1565. [CrossRef] [PubMed]

20. Seifert, S.; Thome, V.; Karlstetter, C. Elektrodynamische Fragmentierung. Eine Technologie zur effektiven Aufbereitung von Abfallströmen. In Recycling und Rohstoffe; Thome-Kozmiensky, K., Ed.; TK Verlag Karl Thome-Kozmiensky: Neuruppin, Germany, 2014; Volume 1, pp. 431-438. ISBN 978-3-944310-10-7.

21. Gehring, F.; Albrecht, S.; Homolka, S.; Leistner, P.; Thome, V.; Seifert, S. Aus Altbeton wird Beton: Ein innovativer Recyclingansatz. Bauphysik 2015, 37, 296-300. [CrossRef]

22. Keller, T.; Streicher-Porte, M.; Schuler, H. Elektrodynamische Fragmentierung von Betonabbruch. In Recy $\mathcal{E}$ DepoTech 2016; Montanuniversität Leoben: Leoben, Austria, 2016.

23. Touze, S.; Bru, K.; Menard, Y.; Weh, A.; Von der Weid, F. Electrical fragmentation applied to the recycling of concrete waste-Effect on aggregate liberation. Int. J. Miner. Process. 2017, 158, 68-75. [CrossRef]

24. Touryan, K.J.; Moeny, W.M.; Aimone, C.T.; Benze, J.W. Electrohydraulic rock fracturing by pulsed power generated focused shocks. In Proceedings of the 7th Pulsed Power Conference, Monterey, CA, USA, 11-14 June 1989; IEEE: Monterey, CA, USA, 1989; pp. 69-72.

25. Martino, R.; Iseli, C.; Gaydardzhiev, S.; Streicher-Porte, M.; Weh, A. Characteristics of End-of-Life Printed Wiring Boards Processed by Electrodynamic Fragmentation. Chem. Ing. Tech. 2017, 89, 152-160. [CrossRef]

26. Duan, C.L.; Diao, Z.J.; Zhao, Y.M.; Huang, W. Liberation of valuable materials in waste printed circuit boards by high-voltage electrical pulses. Miner. Eng. 2015, 70, 170-177. [CrossRef]

27. Weh, A. High Voltage Pulse Fragmentation Technology to Recycle Fibre-Reinforced Composites, SELFRAG CFRP Report Summary, Project ID: 323454. Available online: http:/ / cordis.europa.eu/result/rcn/163622_ en.html (accessed on 29 November 2017).

28. Roux, M.; Eguemann, N.; Giger, L.; Dransfeld, C. High performance thermoplastic composite processing and recycling: from cradle to cradle. In Proceedings of the SAMPE 34th International Technical Conference, Paris, France, 11-12 March 2013; Curran Associates, Inc.: Paris, France, 2013.

29. Roux, M.; Dransfeld, C.; Eguemann, N.; Giger, L. Processing and Recycling of a Thermoplastic Composite Fibre-PEEEK Aerospace part. In Proceedings of the ECCM 16, 16th European Conference on Composite Materials, Sevilla, Spain, 22-26 June 2014; ECCM: Sevilla, Spain, 2014.

30. Bokelmann, K.; Hartfeil, T.; Kunkel, K.; Binnewies, M.; Gellermann, C.; Stauber, R. Neue Methoden zur Wertstoffgewinnung aus primären und sekundären Rohstoffquellen. In Recycling und Rohstoffe; Thome-Kozmiensky, K., Goldmann, D., Eds.; TK Verlag Karl Thome-Kozmiensky: Berlin, Germany, 2017; Volume 1, pp. 427-437. ISBN 978-3-944310-34-3.

31. Orzol, C.; Goldmann, D.; Jäckel, H. Kohlenstofffaserrecycling, Voruntersuchungen zum elektrohydraulischen Aufschluss von kohlenstofffaserverstärktem Duroplast. In Recycling und Rohstoffe; Thome-Kozmiensky, K., Ed.; TK Verlag Karl Thome-Kozmiensky: Berlin, Germany, 2017; Volume 1, pp. 229-233. ISBN 978-3-944310-34-3. 
32. Swiss Equity Magazine Bei Selfrag Bleibt Kein Stein auf Dem Anderen. Available online: http:/ /www.aasa. com/files/7713/8332/6958/SELFRAG_24_May_2011.pdf (accessed on 29 November 2017).

33. ImpulsTec GmbH ImpulsTec, Industrietaugliche Schockwellenzerkleinerung. Available online: https:/ / impulstec.com/de/unternehmen-kontakt/unternehmen (accessed on 29 November 2017).

34. Tipler, P.A.; Mosca, G. Physik für Wissenschaftler und Ingenieure, 7th ed.; Wagner, J., Ed.; Springer: Berlin/Heidelberg, Germany, 2015; ISBN 978-3-642-54166-7.

(C) 2018 by the authors. Licensee MDPI, Basel, Switzerland. This article is an open access article distributed under the terms and conditions of the Creative Commons Attribution (CC BY) license (http://creativecommons.org/licenses/by/4.0/). 